NBER WORKING PAPER SERIES

\title{
ACCESS TO PHYSICIAN SERVICES: DOES SUPPLEMENTAL INSURANCE MATTER? EVIDENCE FROM FRANCE
}

\author{
Thomas C. Buchmueller \\ Agnès Couffinhal \\ Michel Grignon \\ Marc Perronnin \\ Working Paper 9238 \\ http://www.nber.org/papers/w9238 \\ NATIONAL BUREAU OF ECONOMIC RESEARCH \\ 1050 Massachusetts Avenue \\ Cambridge, MA 02138 \\ October 2002
}

We would like to thank for their helpful comments on earlier versions of this paper: Franck Durand, Randall Ellis, Pierre-Yves Geoffard, Ulf Gerdtham, Christine Meyer, Carol Propper, Lise Rochaix, Martin Schellhorn, as well as the participants to the CREDES research seminar, to the ECuity II Project Workshop in Rome, to the International Health Economics Conference organized at the Hong Kong University of Science and Technology, and SEMINARIS in Paris. An earlier study on a close topic was realized with Karin Szwarcensztein and her input should be acknowledged. The views expressed herein are those of the authors and not necessarily those of the National Bureau of Economic Research.

(C) 2002 by Thomas C. Buchmueller, Agnès Couffinhal, Michel Grignon, and Marc Perronnin. All rights reserved. Short sections of text, not to exceed two paragraphs, may be quoted without explicit permission provided that full credit, including (C) notice, is given to the source. 
Access to Physician Services: Does Supplemental Insurance Matter? Evidence from France Thomas C. Buchmueller, Agnès Couffinhal, Michel Grignon, and Marc Perronnin

NBER Working Paper No. 9238

October 2002

JEL No. I11, I18

\section{ABSTRACT}

In France, public health insurance is universal but incomplete, with private payments accounting for roughly 25 percent of all spending. As a result, most people have supplemental private health insurance. We investigate the effects of such insurance on the utilization of physician services using data from the 1998 Enquête Santé Protection Sociale, a nationally representative survey of the French population. Our results indicate that insurance has a strong and significant effect on the utilization of physician services. Individuals with supplemental coverage have substantially more physician visits than those without. In a context where patients are free to choose their provider, we find no evidence that adults with supplemental insurance are more likely to visit a specialist than a general practitioner.

Thomas C. Buchmueller

Graduate School of Management

University of California, Irvine

Irvine, CA 92697-3125

and NBER

tcbuchmu@uci.edu

Agnes Couffinhal

CREDES

1 rue Paul Cézanne

75008 Paris

couffinhal@credes.fr
Michel Grignon

CREDES

1 rue Paul Cézanne

75008 Paris

grignon@credes.fr
Marc Perronin

CREDES

1 rue Paul Cézanne

75008 Paris

perronin@credes.fr 


\section{INTRODUCTION}

In France, as in many other European countries, a publicly financed system provides universal health insurance coverage, but that coverage is not complete. France's Social Security system covers roughly 75 percent of the overall individual health expenditures. The remaining 25 percent consists of co-payments for basic services, spending on services that are either not covered or poorly covered by the public system and provider charges in excess of official reimbursement amounts. In response to these gaps in the public system, 85 percent of the French population has supplemental health insurance.

The effects of supplemental insurance coverage on medical care utilization are of considerable interest to health economists and policy makers, as they have significant implications for both economic efficiency and equity. The issue of efficiency relates to how supplemental insurance interacts with the public system. Like public financing schemes in other countries, the French system imposes cost-sharing on patients as a strategy for controlling utilization [1]. Because most insurance policies reimburse patients for their out-of-pocket payments, supplemental insurance is likely to render ineffective the desired incentive effect, raising both total and public sector health spending, and reducing economic welfare.

The utilization effects of supplemental insurance also have significant implications for equity. Private health expenditures in France are more regressive than in other countries, with the exception of the US and Switzerland [2]. While France rates very highly in terms of life expectancy and other health indicators, the aggregate figures obscure large differences related to income and social class [3]. The fact that both supplemental insurance coverage and access to 
medical care are positively related to income and social class raises the concern that the limitations in the coverage provided by the public system may contribute to the inequity in health outcomes. Seeking to reduce these inequities in access, in 2000 the French government introduced a new means-tested program, the couverture maladie universelle (CMU), to supplement the health insurance coverage provided by the Social Security system so as to reduce the out-of-pocket costs faced by low-income patients.

As a starting point for understanding the impact of this policy on health spending and access to care, it is useful to examine the relationship between supplemental insurance coverage and utilization in the period just prior to the implementation of the CMU. Using a nationally representative survey of the French population conducted in 1998, we investigate the two most important ways that health insurance is likely to affect health spending. First, by lowering the cost of care, insurance may cause a general increase in the quantity of medical care demanded, thus increasing the number of visits. Second, we consider whether supplemental coverage influences the choice of provider, conditional on seeking care. Specifically, we examine the effect of insurance on the choice between seeing a specialist rather than a general practitioner (GP).

The greatest challenge with this type of analysis is distinguishing a causal effect of health insurance-i.e., moral hazard-from the effect of unobserved heterogeneity-i.e., adverse selection. The most obvious concern is that individuals with greater expected medical care usesay, for reasons of poor health—may be more likely to purchase supplemental insurance. If this is the case, the empirical relationship between insurance and utilization will overstate the moral hazard effect. We address this issue in several ways. First, the fact that our data includes detailed 
information on individual health status allows us to investigate the relationship between health risk and insurance coverage. While it does not rule out the possibility of selection based on unobservable characteristics, the richness of the health variables in our data provides a strong test for health-related adverse selection. The inclusion of these variables in our utilization regressions also mitigates concerns that our estimated insurance effects are driven by differences in health status between people with and without private insurance. Second, using a strategy previously employed by Ettner [4] and Genier [5], we contrast the effects of insurance that is obtained through the workplace with individually purchased coverage. To the extent that adverse selection is an issue in the market for supplemental insurance, the problem should be limited to policies purchased directly by individuals. We also estimate several bivariate probit models that treat insurance coverage and the probability of having a physician visit as jointly determined outcomes.

Our results point to a strong effect of supplemental health insurance on the use of physician services. Probit models of the insurance coverage provide no support for the hypothesis that people with supplemental insurance are "sicker" than those without such coverage. Models of the effect of insurance on physician visits indicate a large and statistically significant effect and the magnitude of the effect is comparable for individually purchased and employer-provided insurance. Similarly, the point estimates from bivariate probit models are essentially the same as those from simpler models that treat supplemental insurance as exogenous. Taken together, these results support a moral hazard interpretation of the effect of the relationship between supplemental health insurance and the use of physician services.

The following two sections summarize the key aspects of the French health care system and 
review the relevant empirical literature, respectively. Section IV describes our data and Section V presents our regression results. Concluding comments are in the sixth and final section.

\section{HEALTH INSURANCE AND ACCESS TO CARE IN FRANCE}

All legal residents of France are covered by public health insurance, which is one of the Social Security system's entitlement programs. Between 1980 and 1995, the public sector's share of spending on health care services declined from $79.4 \%$ to almost $75 \%$; it has stayed roughly at that level since then. This trend has coincided with an increase in the proportion of the population with private supplemental health insurance. Whereas in 1970 roughly one-half of the population had such coverage, throughout the 1990 s the figure increased to $85 \%$, with private insurance accounting for half of all private health expenditures.

Because roughly half of all supplemental insurance contracts are provided through the workplace, industrial/occupational affiliation is an important factor determining health insurance coverage. Coverage tends to be higher for managers and highly educated professionals than for semi-skilled and unskilled workers, and is lowest for the unemployed [6]. The vast majority of individually purchased policies are through non-profit organizations known as mutuelles, which are organized largely on occupational, professional or regional lines and which neither exclude potential subscribers on the basis of health nor use risk-rated premiums. Some institutions increase the premium when individuals retire but the adjustment is highly regulated and far from actuarial. About one-quarter of individually purchased coverage is through for-profit insurers who can legally use health status in the underwriting process.

Whereas in other countries supplemental coverage provides access to providers operating outside the public system or a means of "jumping the queue" to obtain hospital or specialty care, 
this is not the case in France. Patients with and without private coverage see the same physicians and neither face any explicit constraints on access. Patients can see as many physicians as they like, as often as they like, and do not need a referral to see a specialist. Thus, in the French system, the main benefit provided by private insurance is to reduce out-of-pocket payments.

In the case of physician visits, there are two sources of out-of-pocket payments: the ticket modérateur, an official co-payment set by the government, and the difference between a provider's fee and the "standard tariff", which is the maximum amount reimbursed by the public system. Out-of-pocket costs are higher for specialists in part because the ticket modérateur is defined as a fixed percentage of the standard tariff, which is higher for specialists, and because specialists are more likely to balance bill. Thirty-eight percent of specialists are allowed to charge more than the standard tariff, compared to $11 \%$ of GPs.

In principle, supplemental insurance may induce substitution away from GPs toward specialists by reducing the price difference between the two types of providers. This may be viewed as an effect of insurance on patient demand for quality, particularly in France where the hierarchical nature of medical education is likely to contribute to a perception that specialists provide a higher quality of care. However, the magnitude of this effect in the current French context may be small as the price difference between specialists and generalists is not generally large. At the time of our data, the standard tariffs were 22.9 euros for specialists and 17.5 euros for GPs, which translates to less than a 2 euro difference in the ticket modérateur. The amount by which specialist fees exceeds the amount reimbursed by the public system varies. In our data, average total charges for specialist and generalist visits would translate to out-of-pocket payments of roughly 15.5 and 6.6 euros, respectively. 


\section{PREVIOUS RESEARCH ON SUPPLEMENTAL INSURANCE AND UTILIZATION}

Although there is a large literature on the effects of health insurance on medical care utilization, most studies are from the US and, for various reasons, are of limited applicability to France and other European countries. The best-known research comes from the Rand Health Insurance Experiment [7]. Individuals randomly assigned to a plan with first dollar coverage had $37 \%$ more physician visits than those facing co-insurance rates of $25 \%$ and $50 \%$ more than individual with $50 \%$ coinsurance. These are the results that are most relevant to the French experience since French patients with comprehensive supplemental insurance face co-insurance rates for ambulatory that are close to zero, compared to rates of between $25 \%$ and $50 \%$ for individuals without supplemental coverage.

More recent US studies use data from large, cross-sectional data sets that, similar to the French data we use, include considerable information on health status as well as economic and socio-demographic variables $[8,9,10]$. Controlling for observable individual characteristics, these studies find that uninsured adults have roughly half as many physician visits per year as the insured. Perhaps more relevant to the French system are studies on the effects of private "Medigap" insurance, which supplements Medicare coverage for elderly Americans. A number of studies find that Medigap coverage is positively associated with utilization $[11,4,12]$ though it is unclear how much of this effect represents moral hazard and how much is due to selfselection.

Research from several European countries indicates a significant positive effect of supplemental private health insurance on outpatient utilization (for instance Harmon and Nolan 
[13] for Ireland, Vera-Hernandez [14] for Spain, and Schellhorn [15] for Switzerland) while others concentrate on hospital care [16]. Most relevant to our work are several prior studies focusing on France. Chiappori et al. [17] analyze a natural experiment resulting from the response of a private supplemental insurer to a change in cost-sharing required by the public system. They compare changes in utilization for a reference group for whom coverage was nearly complete and constant over time and a "treatment group" that experienced a slight increase in required cost sharing. While this approach mitigates the problem of selection bias, it raises other problems relating to the generalizability of the results. All the individuals analyzed had supplemental insurance and even after the regime change the cost sharing required of the "treatment group" was quite modest. These facts combined with the likelihood that individuals in both groups had higher than average incomes, may explain their finding that co-insurance had little effect on use. Differences in utilization between individuals with and without any supplemental coverage may be greater, especially in a broader population.

Three other French studies use nationally representative data. Mormiche [18] presents descriptive evidence on the relationships among social class, medical care utilization, and insurance coverage. Individuals from higher income occupations have more physician visits overall and, conditional on having any visits, are more likely to receive care from specialists. Access to supplemental insurance coverage also varies with income and social class. However, because they do not control for other factors, these correlations are difficult to interpret. Two other studies [19,5] use data from 1980 and 1991-92 to examine the relationship between supplemental insurance and utilization with regressions that control for income and a limited set of health and demographic variables. Both studies find significant effects of insurance on the probability of having any physician visits, but no significant effect on the number of visits 
conditional on having any.

As noted in the introduction, insurance coverage may be endogenous with respect to utilization. Many studies treat insurance as exogenous and rely on extensive health-related control variables to mitigate the bias due to unobserved heterogeneity. Ettner [4] takes an innovative approach to disentangling moral hazard and adverse selection effects of Medigap insurance. First, she estimates models of the determinants of Medigap coverage to test for adverse selection based on observable health status. Then, in her utilization regressions she distinguishes between Medigap coverage provided by a former employer and individually purchased policies. The idea is that adverse selection is unlikely to be a major issue for employer-provided coverage, but may be for individually purchased plans. A third set of studies uses a variety of multiple equation strategies (e.g. bivariate probit, instrumental variables). In our work, we use all of these methods.

There has been much less research on the effect of insurance on the choice between specialists and generalists. Marquis [20] addresses this question using data from the Rand experiment and generally finds no effect. Using survey data from the US, Cooper et al. [21] (1996) find that among the non-elderly, uninsured patients are no less likely to see specialists than those with private insurance. For patients over age 65 , they find a significant and positive relationship between supplemental health insurance and the decision to see a specialist. Apart from the descriptive results presented by Mormiche [18] this question has not been examined for France or other European countries. 


\section{DATA AND DESCRIPTIVE EVIDENCE}

Our data are from the enquête sur la santé et la protection sociale (ESPS), a national household survey conducted by CREDES every other year. In 1998, 7,996 households were interviewed. In this study, we focus on the behavior of adults ages 25 and above. A small fraction of the French population is exempted from the payment of ticket modérateur either because of high cost chronic conditions or extremely low incomes. It is difficult to classify their insurance status because this exemption provides less financial protection than typical supplemental policies, and yet these individuals do not face the same prices as the uninsured. For this reason, and the fact that eligibility for these exemptions is linked to variables that could influence both utilization and the demand for insurance (most notably poor health), we exclude these individuals from our analysis. It should be noted that because people who receive an exemption are less likely than average to hold private supplemental insurance the percentage of people in our sample without coverage is less than in the population. Since health status is a crucial control variable for analyzing medical care utilization, we also exclude respondents who did not complete the part of the survey pertaining to health. Our sample consists of 8,689 individuals.

ESPS respondents are asked to keep a record of all medical consumption during a month, including information on the nature of the good or service consumed, the medical condition that prompted the utilization, the type of professional providing the service, the content of the visit, and the amount charged for the care. The main advantage of this survey methodology is that the utilization data are highly accurate and complete. The cost of this accuracy, however, is that in a one-month period the vast majority of respondents have no utilization, and among users the modal number of visits is one. 
Table 1 presents the distributions for the utilization outcomes that we analyze: visits to any physician, visits to GPs and visits to specialists. The data are presented for the full sample and separately by insurance status. For all three measures, the mean is significantly higher for subsample with supplemental coverage. Considering all types of physicians, those with coverage have nearly twice as many visits as those without ( 0.43 vs. 0.21$)$. A closer investigation reveals that this difference is driven by a difference at the extensive margin: insurance is associated with a doubling of the probability of positive utilization (30\% vs. $14.9 \%)$. For GP and specialists visits, the insurance-related difference in having any visits is 10 and 7 percentage points, respectively, which are large effects given sample means for these outcomes. Conditional on having at least one visit, there is not a statistically significant difference in the mean number of visits for the two groups. Given this pattern, our econometric analysis will focus mainly on the effect of insurance on the probability of having any visits.

Summary statistics for our independent variables are reported in Table 2. The ESPS provides information on the source of each person's insurance coverage. Because employerprovided health insurance represents a relatively small share of total compensation in France and comparable insurance is readily available outside the workplace, there is no reason to expect workers to choose jobs based on their demand for insurance. As a result, to the extent that adverse selection is an issue in the French system it should be limited to individually purchased contracts. Therefore, following Ettner [4] and Genier [5], we can test for adverse selection by comparing the effect of these two types of policies on utilization. The validity of this test rests on the comparability of the two types of coverage. While limited, the information on the quality of coverage that is available in the ESPS does not point to large differences in quality. When asked about the quality of reimbursement for specialized care, $45 \%$ of respondents with group 
insurance and $43 \%$ of persons with individual contracts said their coverage was complete.

The potential for bias from unobserved heterogeneity is also reduced by the fact that the ESPS includes a rich set of health status measures and other controls. Self-assessed global health status is measured using a 10-point scale. We use this variable to construct indicator variables for people in excellent health and those whose health is fair or poor. Respondents are also asked to list their medical conditions, to report information about risk factors (smoking) and to say whether or not they frequently experience pain or difficulties in performing daily activities. Based on responses to these questions, physician researchers have constructed categorical variables reflecting mortality risk and levels of disability. In our analysis, we use this information to construct indicators for individuals with a high mortality risk and for those reporting some type of disability. Our regressions also include three dummy variables relating to smoking, a dummy for individuals who report experiencing frequent pain, and one for women who are pregnant at the time of the survey.

Demographic and economic control variables include age, gender, family income (reported in intervals and normalized by the number of consumption units in the family), education, employment status and occupation/labor force activity. Two additional control variables describe whether the individual lives in a region where the density of physician is high or low.

\section{RESULTS}

\section{The Determinants of Supplemental Insurance Coverage}

An important first step in testing for adverse selection is to examine the effect of observed health status on insurance coverage. The first column of Table 3 reports results from a probit regression in which the dependent variable equals one for individuals with private supplemental 
health insurance and zero for those without. In the next two columns, we report coefficients from a multinomial logit model with three outcomes: no supplemental insurance (the base category), employer-provided insurance and individually-purchased coverage. Slightly more than half the people with supplemental insurance, receive it from the workplace. For both models the regressors include seven health status variables, four indicators of smoking behavior along with other economic and demographic controls.

First and foremost, we find no evidence that individuals in poor health are more likely to obtain supplemental insurance. Some of the probit coefficients indicate a positive relationship between poor health and coverage, though others have the opposite sign. Most importantly none of the health coefficients are statistically significant individually and they are insignificant as a group as well. This result is consistent with the findings of Hurd and McGarry [12] for Medigap insurance in the US, Shmueli [22] for supplemental insurance in Israel, as well as Genier [5] on a different French survey. Our results are stronger than those studies because we have substantially more information on health status. Similarly, the multinomial logit results indicate no significant relationship between health and insurance coverage.

In contrast, we do find a significant relationship between smoking behavior and coverage. Evaluating the probit function at the sample means implies that heavy (light) smokers are 3.5 (1.8) percentage points less likely than non-smokers to have private insurance. One possible interpretation is that smokers have a higher tolerance for risk and/or place a lower value on their health than non-smokers. However, answers to subjective questions that were addressed to only a subset of ESPS respondents seem to argue against the idea of self-selection on the basis of "tastes". These questions ask respondents to state what influence they believe medical care and 
other factors (work conditions, family tensions and the environment) have on health. Individuals with and without supplemental coverage answer these questions quite similarly. In particular, there is no statistically significant difference in the percentage saying that medical care is either important or very important.

The other coefficients confirm that socioeconomic status has a significant impact on the probability of having supplemental insurance. Coverage increases with income and, relative to working adults, is lower for the unemployed and higher for retirees. The marginal effect of age on any supplemental insurance coverage is quadratic, with the probability of coverage increasing until age 43 and declining thereafter. However, this result is somewhat deceiving given the large positive effect of being retired. The multinomial logit results reveal that age is not significantly related to individual purchases of insurance relative to having no supplemental coverage. Since medical care utilization increases with age, this also runs counter to the notion that this market is subject to adverse selection.

\section{The Effect of Supplemental Insurance on Physician Visits}

Table 4 presents results for probit models in which the dependent variable equals one for individuals with at least one visit to any type of physician and zero otherwise. In column 1 , insurance is represented by a single indicator variable; the model in column 2 allows for a differential effect of insurance by source of coverage.

Turning first to the controls, all of the health status variables have a statistically significant effect on utilization, which suggests that these measures capture different aspects of health. All else equal, individuals with the poorest self-assessed health are 9 percentage points more likely to have a visit than our baseline health category, who are themselves 10 percentage points more 
likely to have a visit than individuals with the best self-assessed health. Heavy smokers have slightly lower utilization than non-smokers (a 3 percentage point difference), while former smokers have more (by 5 percentage points). Utilization is significantly higher for women than for men and pregnancy substantially increases utilization by women. Utilization increases slightly with income and education.

The effect of insurance is large and statistically significant. The results in column 1 show that controlling for individual characteristics, supplemental insurance increases the probability of having at least one physician visit by nearly 13 percentage points, which is roughly $80 \%$ of the raw difference reported in Table 1. To put this in some perspective, this effect is approximately twice the magnitude of the difference in utilization between the highest and lowest income categories; the effect of insurance is smaller than the difference in utilization between the least healthy and the healthiest individuals in the sample.

In column 2, the coefficient on employer-provided insurance is slightly larger than that for individually purchased coverage. This is the opposite of what we should find if the relationship between insurance and utilization were being driven by adverse selection. However, like in Genier [5], the difference between the two coefficients is not different from zero at standard levels of significance. The coefficients on the control variables are very similar across the two specifications.

An alternative strategy to account for the potential endogeneity of insurance is to estimate insurance coverage and utilization jointly using a bivariate probit model. The key issue here is to identify variables that can reasonably be assumed to influence coverage, but no direct impact on utilization. Variables related to occupation and labor force status are the most viable candidates 
in the ESPS, with the most plausible instrument being an indicator of employment in the public sector. All public employees are able to participate in mutual insurance contracts designed for civil servants, and most of them take up these contracts, but there is no reason to expect employment in the public sector to have an impact on health status or the consumption of care. In fact, in our data, there is no significant difference in the observed health of public employees and other adults and when this indicator variable is included directly in the utilization regression (controlling for insurance coverage) its coefficient is not statistically different from zero. Variables describing employment status (five categories) and professional occupation (eight categories) are also candidate instruments which have been use in other studies (for instance, Vera-Hernandez [14]).

Table 5 presents the main results for bivariate probit models that exclude different combinations of variables from the utilization equation, while maintaining them in the equation for insurance coverage (note that we include all these variables in the models reported in table 4 and none of their coefficients are significant). Since the results for the control variables are essentially the same as in Tables 3 and 4, we report only the supplemental insurance coefficient, the estimate of the correlation between the error terms of the coverage and utilization equations ( $\rho$ ) and the likelihood ratio for testing the bivariate probit model to the simpler (restricted) model in which coverage and utilization are estimated separately. We report these results for several versions of the model to show the sensitivity of the results to the assumed exclusion restrictions. Because we believe the theoretical basis of the public employment dummy is stronger than the other two sets of variables, we exclude it from the utilization equation in all bivariate probit specifications. 
Although the point estimates vary somewhat depending on which variables are excluded from the utilization equation, the qualitative results are the same across the different specifications. For all versions of the bivariate probit model, the insurance coefficient is larger than the one from the single equation probit model, though less precisely estimated. The correlation coefficient is negative for all specifications, though it is never statistically significant. Taken at face value, these results would suggest that there is favorable selection into supplemental insurance coverage, which would imply that treating insurance as exogenous leads to an understatement of the true moral hazard effect. However, given the imprecision of the point estimates, a more prudent interpretation is that there is no significant difference between the model that treats insurance as exogenous and the bivariate probit specification. This interpretation is supported by likelihood ratio tests as well as by an alternative test proposed by Lollivier [23].

The pattern of results from the bivariate probit models as well as from the models that use the source of coverage to test for adverse selection support the idea that in France supplemental insurance increases utilization by lowering the out-of-pocket cost of care. This view is also supported by responses to a question in the ESPS about whether in the year prior to the survey the person had foregone seeking care for financial reasons. Individuals without supplemental insurance are substantially more likely to report having foregone care than those with insurance $(32 \%$ vs. $12 \%)$ and the difference remains significant after controlling for other individual characteristics.

We also estimated several other regressions which are not reported, but which we will discuss briefly here. First, we estimated separate probit models of the probability of having any 
GP or specialist visits. As with the results for any visits, for both of these outcomes, the regression-adjusted effect of insurance is nearly as large as the raw difference reported in Table 1. The results for the control variables are also qualitatively similar to those in Table 4 . In particular, all the coefficients on the health status variables are statistically significant with the expected sign. We find no statistically significant difference between the effects of employerprovided and individually purchased insurance. Likewise, bivariate probit results for the probability of having at least one GP or specialist visit contradict the adverse selection hypothesis and give the same qualitative results as the ones described above.

For all three utilization measures, we also estimated models of the total number of visits conditional on positive utilization. Alternative specifications (e.g., OLS, Poisson, negative binomial) yield a consistent finding of no relationship between insurance and conditional visits, which is not surprising given that even the unadjusted data suggest a zero effect of insurance. One possible explanation is that while the decision to seek care is made by patients, subsequent visits are the outcome of the interaction between providers and patients and, therefore, less sensitive to financial factors [24]. However, because in the one-month period so few people have multiple visits, these results should be interpreted with caution.

\section{Insurance and the choice of physician}

As noted above, since cost sharing is generally greater for specialty as compared to primary care, supplemental insurance might also influence the type of physician a patient chooses to see. We test for this type of effect by taking the physician visit as the unit of observation and estimating a probit model of the decision to see a specialist rather than a GP. A key issue here is that the choice between the two types of providers is not relevant for all medical conditions that 
prompt a visit. In many situations visiting a GP is the only reasonable option, whereas other conditions lie clearly within the domain of a specialist. In these extreme cases, while financial considerations may affect the decision of whether or not to seek care, conditional on seeking care there is little reason to expect an effect of insurance on the type of provider chosen.

A more informative test, therefore, is to examine the effect of supplemental insurance on the choice of physician type for conditions where either a GP or specialist could provide the care. We identify such cases according to observed patient behavior in earlier ESPS surveys (19921995). In those data, we group all visits by the ICD-9 code for the condition prompting the visit. For each ICD sub-chapter we calculate the proportion of visits that took place in a specialist's practice and sorted the data according to this measure (excluding sub-chapters for which the number of visits was too small to get a reliable estimate). Then, we distinguish three groups of medical conditions: those which are treated by a specialist in less than $30 \%$ of cases, those treated by a specialist in more than $70 \%$ of cases, and those in between, for which we consider the possibility of substitution to be most likely (results do not vary when these arbitrary thresholds are changed). Thus, in addition to analyzing the full sample of visits (3591 over a month), we estimate a model on the sub-sample that falls in this middle category (1402 visits). In addition to the independent variables used to model the probability of having any visits, we include an indicator of whether or not the visit was referred by a physician.

The full results are reported in Table 6. As expected, the referred visits are much more likely to take place at a specialist's. For the most part, other control variables have limited impact on the type of provider chosen. The effect of insurance is stronger when we limit the analysis to visits where substitution between specialists and GPs seems more plausible. 
However, even there, the impact of insurance is not significantly different from zero.

The lack of a significant effect of insurance on choice of provider may not be surprising given that, as noted in Section II, even for people without supplemental insurance the difference in out-of-pocket cost for a GP and a specialist is often very small. However, this "non-result" is subject to several important caveats. First, because it is difficult to identify exactly those cases where a patient could see either a GP or a specialist, our estimates are necessarily imprecise. When we limit the sample to visits where substitution seems most plausible, the point estimate is actually quite large, but is insignificant because of a large standard error. Thus, while the $95 \%$ confidence interval includes zero, it also includes very large effects.

Second, since we only observe the choice of provider for people who seek care, these results need to be interpreted in light of the strong effect of insurance on that preceding decision. In particular, since out-of-pocket costs are higher for specialists (if only slightly so) the tendency of

uninsured patients to forego care for financial reasons may be greatest in cases where the services in question are those of a specialist. Thus, our results for this conditional decision may be biased toward zero due to self-selection. In principle, one could account for this selection with a Heckman-type model, though in our data there are no variables that can plausibly be argued to affect the decision to seek care but not the choice of provider.

\section{DISCUSSION}

Our main results can be summarized as follows. We find a large and statistically significant difference between French adults with and without supplementary health insurance in the probability of seeing a physician during a one-month period. In contrast, conditional on having at least one visit, we find no statistically significant effect of insurance on the number of visits or 
the type of physician chosen. However, both of these latter results are subject to important caveats. Given the short time period over which utilization is measured in our data, very few people have multiple visits. With respect to the choice of physician, insurance may have a stronger effect in settings where there the difference in out-of-pocket costs for specialists and GPs is more pronounced. Even in the French context, our estimates may be biased downward by the fact that we cannot model the decision to seek care and the choice of provider as joint decisions.

The magnitude of the effect of insurance in our data is comparable to the effect of health status and larger than the partial effect of income. While differences in data preclude precise comparisons, this effect is large relative the findings of previous studies. In percentage terms, the difference we find between individuals with and without supplemental insurance is of a comparable magnitude of the gap in utilization between Americans with and without any insurance and is larger than the percent effects found in the Rand experiment. This might seem to suggest that our estimates of the causal effect of insurance on utilization are biased by adverse selection. However, considerable evidence argues against this interpretation. If adverse selection were an important factor, we would expect individuals whose observed health status was poor to be more likely to purchase insurance. Despite having several different measures of health status, we find no evidence of this kind. Similarly, while these health status measures and other demographic variables are strongly related to utilization, only a small part of the insurancerelated difference in utilization can be explained by differences in observed characteristics of individuals with and without coverage. Two distinct tests for the effect of unmeasured characteristics also provide no support for the adverse selection hypothesis, while auxiliary regressions point to out-of-pocket costs as a factor reducing the utilization of individuals without 
private insurance.

Because in France private health insurance coverage increases with income, the strong effect of insurance on utilization contributes to income-related inequality in access to care. The magnitude of this effect is illustrated in Table 7, which for four income groups reports mean actual utilization and predicted utilization under the assumption that everyone had private supplemental insurance. The latter figures are estimated based on the regression results reported in Table 4. The figures show that in 1998, individuals in the highest income category were $33 \%$ more likely to have at least one physician visit during a one-month period than individuals in the lowest income group (32.5\% vs. $24.4 \%)$. Extending supplemental insurance to the entire population would increase mean utilization for all groups, but the change would be larger for the lower income groups because of their lower baseline level of insurance. Thus, achieving universal coverage in this way would reduce the difference in utilization between the highest and lowest income groups from 8 percentage points to 6.5 percentage points. All in all, these results have direct implications for legislation that was enacted in 2000 with the goal of improving the insurance coverage of low-income families (the $C M U$ ). Our results imply that this policy should increase utilization for the target population, though the effect on overall inequalities in access will be relatively modest. The actual impact of the $C M U$ is an important subject for future research. 
REFERENCES

1. Couffinhal A and Paris V. Utilization fees Imposed to Public Health Systems Users in France. Proceedings of a workshop organized for the Commission on the Future of Health Care in Canada, 2001.

2. Van Doorslaer E and Wagstaff A. Equity in the finance of health care: methods and findings. In Equity in the Finance and Delivery of Health Care, Van Doorslaer E, Wagstaff A and Rutten F (eds). An International Perspective. Oxford University Press: Oxford, 1993.

3. Haut Comité de la santé publique. La santé en France 2002. La documentation française (ed), 2002.

4. Ettner S. Adverse Selection and the Purchase of Medigap Insurance by the Elderly. Journal of Health Economics 1997; 16(5): 543-562.

5. Genier P. Assurance et Recours aux Soins. Revue Economique 1998; 49(3): 808-819.

6. Bocognano A, Couffinhal A, Dumesnil S and Grignon M. La complémentaire maladie en France : qui bénéficie de quels remboursements ? CREDES Report 1317, 2000.

7. Manning WG et al. Health Insurance and the Demand for Medical Care: Evidence from a Randomized Experiment. American Economic Review, 1987; 77(3), 251-77.

8. Spillman BC. The Impact of Being Uninsured on Utilization of Basic Health Care Services. Inquiry 1992; 29(4): 457-66.

9. Hahn B. Health Care Utilization: The Effects of Extending Insurance to Adults on Medicaid or Uninsured. Medical Care 1994; 32(3): 227-239.

10.Marquis MS and Long SH. The Uninsured Access Gap: Narrowing the Estimates. Inquiry 1994-95; 31(4), 405-14.

11.Cartwright $\mathrm{W}, \mathrm{Hu} \mathrm{T}$, and Huang L. Impact of varying Medigap insurance coverage on the use of medical services of the elderly. Applied Economics 1992; 24: 529-539.

12.Hurd MD and McGarry K. Medical Insurance and the Use of Health Care Services by the Elderly. Journal of Health Economics, 1997; 16(2): 129-154.

13.Harmon, C and Nolan B. Health Insurance and Health Services Utilization in Ireland. Health Economics 2001; 10(2): 135-45.

14.Vera-Hernandez AM. Duplicate Coverage and demand for Health Care. The Case of Catalonia. Health Economics 1999; 8(7): 579-98.

15.Schellhorn M. The effect of variable health insurance deductibles on the demand for physician visits. Health Economics 2001; 10(5): 441-456.

16.Holly A, Gardiol L, Domeninghetti G and Bisig B. An econometric model of health care utilization and health insurance in Switzerland. European Economic Review 1998; 42: 513 522. 
17.Chiappori PA Durand F and Geoffard PY. Moral Hazard and the Demand for Physician Services: First Lessons from a French Natural Experiment. European Economic Review 1998; 42: 499-511.

18.Mormiche P. Les disparités de recours aux soins en 1991. Economie et Statistique 1993; 265 : 45-52.

19.Caussat L and Glaude M. Dépenses médicales et couverture sociale. Economie et Statistique 1993; 265: 31-43.

20.Marquis MS. Cost-sharing and Provider Choice. Journal of Health Economics 1985; 4(2), $137-57$.

21.Cooper PF, Nichols LM and Taylor AK. Patient Choice of Physician: Do Health Insurance and Physician Characteristics Matter? Inquiry 1996; 33(3), 237-46.

22.Shmueli A. The Effect of Health on Acute Care Supplemental Insurance Ownership: An Empirical Analysis. Health Economics, 2001; 10(4): 341-350.

23.Lollivier S. Endogénéité d'une variable explicative dichotomique dans le cadre d'un modèle probit bivarié. Annales d'économie et de statistique, 2001; 62: 251-269.

24.Stoddart GL and Barer ML. Analyses of Demand and Utilization through Episodes of Medical Service. In Health, Economics, and Health Economics, Van der Gaag and Perlman (eds) North-Holland Publishing Company, 1981. 
Table 1. The Distribution and Mean Number of Physician Visits Over a Month Period by Insurance Status, Adults over 25

\begin{tabular}{|c|c|c|c|}
\hline & $\begin{array}{c}\text { Full } \\
\text { Sample }\end{array}$ & $\begin{array}{c}\text { No } \\
\text { Supplemental } \\
\text { Insurance }\end{array}$ & $\begin{array}{c}\text { With } \\
\text { Supplemental } \\
\text { Insurance }\end{array}$ \\
\hline \multicolumn{4}{|l|}{ All Visits } \\
\hline 0 & $71.3 \%$ & $85.1 \%$ & $70.0 \%$ \\
\hline 1 & $20.5 \%$ & $11.9 \%$ & $21.3 \%$ \\
\hline 2 & $5.6 \%$ & $1.6 \%$ & $6.0 \%$ \\
\hline 3 or More & $2.6 \%$ & $1.4 \%$ & $2.7 \%$ \\
\hline $\begin{array}{c}\text { Mean } \\
\text { (std. dev.) }\end{array}$ & $\begin{array}{c}0.41 \\
(0.81)\end{array}$ & $\begin{array}{c}0.21 \\
(0.62)\end{array}$ & $\begin{array}{c}0.43 \\
(0.83)\end{array}$ \\
\hline \multicolumn{4}{|l|}{ GP Visits } \\
\hline 0 & $79.0 \%$ & $88.3 \%$ & $78.2 \%$ \\
\hline 1 & $17.9 \%$ & $10.9 \%$ & $18.5 \%$ \\
\hline 2 & $2.6 \%$ & $0.5 \%$ & $2.8 \%$ \\
\hline 3 or More & $0.5 \%$ & $0.3 \%$ & $0.5 \%$ \\
\hline $\begin{array}{c}\text { Mean } \\
\text { (st. dev.) }\end{array}$ & $\begin{array}{c}0.25 \\
(0.53)\end{array}$ & $\begin{array}{c}0.13 \\
(0.38)\end{array}$ & $\begin{array}{c}0.26 \\
(0.54)\end{array}$ \\
\hline \multicolumn{4}{|l|}{ Specialist Visits } \\
\hline 0 & $88.1 \%$ & $94.7 \%$ & $87.5 \%$ \\
\hline 1 & $8.9 \%$ & $3.9 \%$ & $9.4 \%$ \\
\hline 2 & $2.1 \%$ & $0.8 \%$ & $2.2 \%$ \\
\hline 3 or More & $0.9 \%$ & $0.6 \%$ & $0.9 \%$ \\
\hline $\begin{array}{c}\text { Mean } \\
\text { (std. dev.) }\end{array}$ & $\begin{array}{c}0.16 \\
(0.56)\end{array}$ & $\begin{array}{c}0.08 \\
(0.41)\end{array}$ & $\begin{array}{c}0.17 \\
(0.57)\end{array}$ \\
\hline $\begin{array}{l}\text { Number of } \\
\text { Observations }\end{array}$ & 8,689 & 738 & 7,951 \\
\hline
\end{tabular}


Table 2: Sample Characteristics

\begin{tabular}{|c|c|c|c|}
\hline & $\begin{array}{c}\text { Full } \\
\text { Sample }\end{array}$ & \begin{tabular}{c}
\multicolumn{1}{c}{ No } \\
Supplement \\
al insurance \\
\end{tabular} & $\begin{array}{c}\text { With } \\
\text { supplemental } \\
\text { insurance } \\
\end{array}$ \\
\hline$\overline{\text { Age (Years) }}$ & 46.3 & 44.5 & 46.4 \\
\hline Male & $48.4 \%$ & $52.3 \%$ & $48 \%$ \\
\hline Married & $82.4 \%$ & $65.6 \%$ & $83.9 \%$ \\
\hline Primary Education & $19.4 \%$ & $22.8 \%$ & $19.1 \%$ \\
\hline Secondary Education & $37.2 \%$ & $37.8 \%$ & $37.1 \%$ \\
\hline High School & $15.8 \%$ & $13.1 \%$ & $16.0 \%$ \\
\hline Higher Education & $24.5 \%$ & $21.4 \%$ & $24.8 \%$ \\
\hline Unknown & $3.1 \%$ & $4.9 \%$ & $3.0 \%$ \\
\hline \multicolumn{4}{|l|}{ HH Income/Consumption Unit } \\
\hline Less than $€ 305$ & $3.2 \%$ & $8.9 \%$ & $2.6 \%$ \\
\hline$€ 306$ to 457 & $8.4 \%$ & $19.8 \%$ & $7.4 \%$ \\
\hline$€ 458$ to 610 & $10.8 \%$ & $13.6 \%$ & $10.5 \%$ \\
\hline$€ 611$ to 762 & $12.6 \%$ & $9.9 \%$ & $12.9 \%$ \\
\hline$€ 763$ to 915 & $12.7 \%$ & $11.5 \%$ & $12.8 \%$ \\
\hline$€ 916$ to 1,220 & $16.0 \%$ & $8.3 \%$ & $16.8 \%$ \\
\hline More than $€ 1,220$ & $22.8 \%$ & $13.3 \%$ & $23.7 \%$ \\
\hline Unknown & $13.5 \%$ & $14.8 \%$ & $13.4 \%$ \\
\hline \multicolumn{4}{|l|}{ Self Assessed Health Status } \\
\hline Fair and Poor & $12.3 \%$ & $14.1 \%$ & $12.1 \%$ \\
\hline Good & $61.3 \%$ & $54.9 \%$ & $61.8 \%$ \\
\hline Excellent & $21.5 \%$ & $24.5 \%$ & $21.2 \%$ \\
\hline Unknown & $5.0 \%$ & $6.5 \%$ & $4.9 \%$ \\
\hline High Mortality Risk & $18.6 \%$ & $17.2 \%$ & $18.7 \%$ \\
\hline Disabled & $18.7 \%$ & $17.3 \%$ & $18.8 \%$ \\
\hline Experiencing Frequent Pain & $15.6 \%$ & $16.5 \%$ & $15.5 \%$ \\
\hline Pregnant Women & $1.0 \%$ & $0.5 \%$ & $1.1 \%$ \\
\hline Former Smoker & $21.6 \%$ & $14.5 \%$ & $22.3 \%$ \\
\hline Light Smoker & $11.6 \%$ & $14.2 \%$ & $11.3 \%$ \\
\hline Heavy Smoker & $14.4 \%$ & $21.8 \%$ & $13.7 \%$ \\
\hline Non-smoker & $52.4 \%$ & $49.5 \%$ & $52.7 \%$ \\
\hline Not in the Labor Market & $8.7 \%$ & $12.9 \%$ & $8.3 \%$ \\
\hline Employed & $66.7 \%$ & $56.5 \%$ & $67.6 \%$ \\
\hline Unemployed & $5.6 \%$ & $16.0 \%$ & $4.6 \%$ \\
\hline Retired & $18.2 \%$ & $12.3 \%$ & $18.7 \%$ \\
\hline Student & $0.9 \%$ & $2.3 \%$ & $0.8 \%$ \\
\hline Farmer & $4.5 \%$ & $5.3 \%$ & $4.4 \%$ \\
\hline Artisan Retailer & $5.3 \%$ & $8.9 \%$ & $4.9 \%$ \\
\hline Executive/Professional & $12.4 \%$ & $8.8 \%$ & $12.8 \%$ \\
\hline Technical Profession & $20.5 \%$ & $10.3 \%$ & $21.5 \%$ \\
\hline Other Employees & $28.9 \%$ & $26.8 \%$ & $29.1 \%$ \\
\hline Skilled Workers & $16.5 \%$ & $16.8 \%$ & $16.5 \%$ \\
\hline Unskilled Workers & $8.5 \%$ & $16.0 \%$ & $7.8 \%$ \\
\hline Occupation Unknown & $3.2 \%$ & $7.0 \%$ & $2.9 \%$ \\
\hline Public employee & $24.7 \%$ & $14.1 \%$ & $25.7 \%$ \\
\hline High Density of Physicians & $22.5 \%$ & $37.7 \%$ & $21.1 \%$ \\
\hline Low Density of Physicians & $7.4 \%$ & $7.6 \%$ & $7.4 \%$ \\
\hline Number of Observations & 8,689 & 738 & 7,951 \\
\hline
\end{tabular}


Table 3. Determinants of Supplemental Insurance Coverage

\begin{tabular}{|c|c|c|c|}
\hline Model: & \multirow{2}{*}{$\begin{array}{c}\text { Probit } \\
\text { Any Private } \\
\text { Insurance }\end{array}$} & \multicolumn{2}{|c|}{ Multinomial Logit } \\
\hline Outcome: & & $\begin{array}{c}\text { Employer- } \\
\text { Provided }\end{array}$ & $\begin{array}{l}\text { Individually- } \\
\text { Purchased }\end{array}$ \\
\hline Age & $\begin{array}{c}0.024 * \\
(0.0096)\end{array}$ & $\begin{array}{l}0.114^{* *} \\
(0.021)\end{array}$ & $\begin{array}{c}0.017 \\
(0.019)\end{array}$ \\
\hline $\operatorname{Age}^{2}$ & $\begin{array}{l}-0.0003 * * \\
(0.0001)\end{array}$ & $\begin{array}{l}-0.0012 * * \\
(0.0002)\end{array}$ & $\begin{array}{l}-0.0003 \\
(0.0002)\end{array}$ \\
\hline Male & $\begin{array}{l}-0.18 * * \\
(0.05)\end{array}$ & $\begin{array}{l}-0.36^{* *} \\
(0.11)\end{array}$ & $\begin{array}{l}-0.34 * * \\
(0.11)\end{array}$ \\
\hline Married & $\begin{array}{l}0.55 * * \\
(0.05)\end{array}$ & $\begin{array}{l}1.44 * * \\
(0.11)\end{array}$ & $\begin{array}{l}0.78 * * \\
(0.10)\end{array}$ \\
\hline Secondary Education & $\begin{array}{c}0.08 \\
(0.07)\end{array}$ & $\begin{array}{c}0.15 \\
(0.13)\end{array}$ & $\begin{array}{c}0.17 \\
(0.13)\end{array}$ \\
\hline High School Education & $\begin{array}{c}0.09 \\
(0.08)\end{array}$ & $\begin{array}{c}0.21 \\
(0.17)\end{array}$ & $\begin{array}{c}0.16 \\
(0.17)\end{array}$ \\
\hline Higher Education & $\begin{array}{l}-0.01 \\
(0.09)\end{array}$ & $\begin{array}{c}0.00 \\
(0.18)\end{array}$ & $\begin{array}{l}-0.03 \\
(0.18)\end{array}$ \\
\hline Education Unknown & $\begin{array}{l}-0.13 \\
(0.12)\end{array}$ & $\begin{array}{l}-0.54^{*} \\
(0.24)\end{array}$ & $\begin{array}{l}-0.27 \\
(0.23)\end{array}$ \\
\hline Income: $€ 306$ to 457 & $\begin{array}{c}0.10 \\
(0.10)\end{array}$ & $\begin{array}{c}0.43 \\
(0.22)\end{array}$ & $\begin{array}{c}0.07 \\
(0.19)\end{array}$ \\
\hline Income: $€ 458$ to 610 & $\begin{array}{l}0.43 * * \\
(0.11)\end{array}$ & $\begin{array}{l}1.17 * * \\
(0.22)\end{array}$ & $\begin{array}{l}0.57 * * \\
(0.20)\end{array}$ \\
\hline Income: $€ 611$ to 762 & $\begin{array}{l}0.66^{* *} \\
(0.11)\end{array}$ & $\begin{array}{l}1.68 * * \\
(0.23)\end{array}$ & $\begin{array}{l}0.95 * * \\
(0.21)\end{array}$ \\
\hline Income: $€ 763$ to 915 & $\begin{array}{l}0.55 * * \\
(0.11)\end{array}$ & $\begin{array}{l}1.55^{* *} \\
(0.23)\end{array}$ & $\begin{array}{l}0.72 * * \\
(0.21)\end{array}$ \\
\hline Income: $€ 916$ to 1,220 & $\begin{array}{l}0.82 * * \\
(0.11)\end{array}$ & $\begin{array}{l}2.24 * * \\
(0.24)\end{array}$ & $\begin{array}{l}1.22 * * \\
(0.22)\end{array}$ \\
\hline Income: More than $€ 1,220$ & $\begin{array}{l}0.81 * * \\
(0.11)\end{array}$ & $\begin{array}{l}2.16^{* *} \\
(0.23)\end{array}$ & $\begin{array}{l}1.10^{* *} \\
(0.21)\end{array}$ \\
\hline Income Unknown & $\begin{array}{l}0.52 * * \\
(0.10)\end{array}$ & $\begin{array}{l}1.41 * * \\
(0.22)\end{array}$ & $\begin{array}{l}0.71 * * \\
(0.20)\end{array}$ \\
\hline Self-Assessed Health = Fair/Poor & $\begin{array}{l}-0.05 \\
(0.07)\end{array}$ & $\begin{array}{l}-0.08 \\
(0.15)\end{array}$ & $\begin{array}{l}-0.07 \\
(0.14)\end{array}$ \\
\hline Self-Assessed Health $=$ Excellent & $\begin{array}{l}-0.05 \\
(0.05)\end{array}$ & $\begin{array}{l}-0.08 \\
(0.11)\end{array}$ & $\begin{array}{l}-0.11 \\
(0.11)\end{array}$ \\
\hline Self-Assessed Health $=$ Unknown & $\begin{array}{l}-0.06 \\
(0.09)\end{array}$ & $\begin{array}{l}-0.17 \\
(0.19)\end{array}$ & $\begin{array}{l}-0.05 \\
(0.18)\end{array}$ \\
\hline Moderate to High Mortality Risk & $\begin{array}{c}0.10 \\
(0.06)\end{array}$ & $\begin{array}{c}0.16 \\
(0.13)\end{array}$ & $\begin{array}{c}0.18 \\
(0.13)\end{array}$ \\
\hline Disabled & $\begin{array}{c}0.09 \\
(0.07)\end{array}$ & $\begin{array}{c}0.16 \\
(0.14)\end{array}$ & $\begin{array}{c}0.16 \\
(0.14)\end{array}$ \\
\hline Experiencing Frequent Pain & $\begin{array}{l}-0.03 \\
(0.06)\end{array}$ & $\begin{array}{l}-0.05 \\
(0.13)\end{array}$ & $\begin{array}{l}-0.03 \\
(0.13)\end{array}$ \\
\hline Pregnant Woman & $\begin{array}{c}0.28 \\
(0.26)\end{array}$ & $\begin{array}{c}0.33 \\
(0.56)\end{array}$ & $\begin{array}{c}0.71 \\
(0.54)\end{array}$ \\
\hline Former Smoker & $\begin{array}{c}0.05 \\
(0.06)\end{array}$ & $\begin{array}{c}0.14 \\
(0.13)\end{array}$ & $\begin{array}{c}0.10 \\
(0.13)\end{array}$ \\
\hline Light Smoker & $\begin{array}{l}-0.14 * \\
(0.07)\end{array}$ & $\begin{array}{l}-0.31 * \\
(0.13)\end{array}$ & $\begin{array}{l}-0.24 \\
(0.13)\end{array}$ \\
\hline Heavy Smoker & $\begin{array}{l}-0.26^{* *} \\
(0.06)\end{array}$ & $\begin{array}{l}-0.43 * * \\
(0.13)\end{array}$ & $\begin{array}{l}-0.48 * * \\
(0.13)\end{array}$ \\
\hline
\end{tabular}


Table 3, Continued

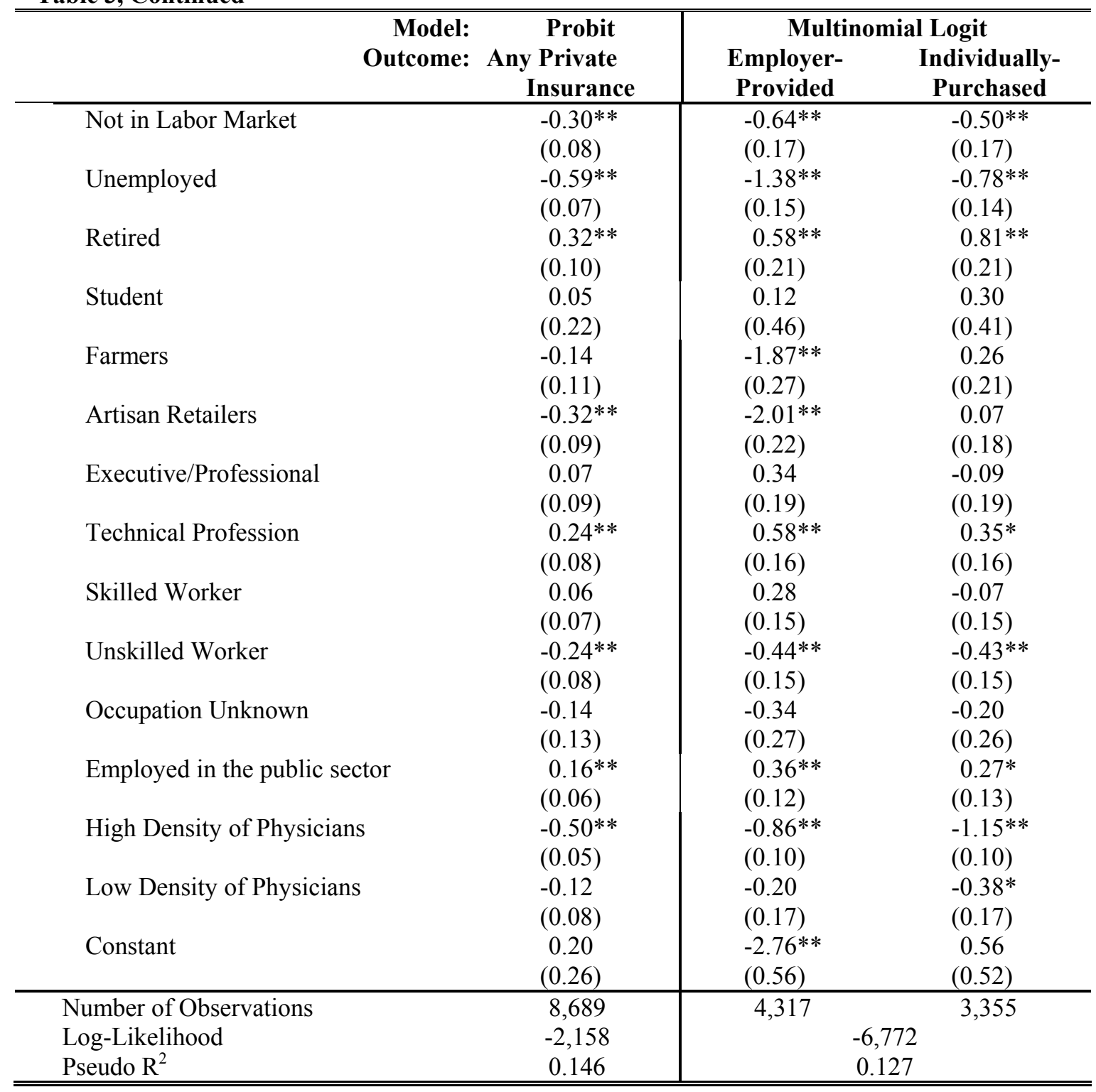

Notes: For the probit model, the dependent variable is equal to 1 for individuals with private supplemental insurance and zero for those without. No insurance is also the reference category for the multinomial logit. The income variable represents household income per consumption unit.

** : significant at the $1 \%$ level, * : $5 \%$ level. Standard errors in parentheses. 
Table 4. The Probability of Any Physician Visit, Full Regression Results

\begin{tabular}{|c|c|c|}
\hline & $\begin{array}{c}\text { Indicator of } \\
\text { coverage }\end{array}$ & $\begin{array}{l}\text { Employ. based or } \\
\text { Indiv. purchased }\end{array}$ \\
\hline Covered by any supplemental insurance & $\begin{array}{l}0.44 * * \\
(0.06) \\
{[0.13]}\end{array}$ & ------ \\
\hline Employment-based Supplemental Insurance & ----- & $\begin{array}{l}0.46^{* *} \\
(0.07) \\
{[0.15]}\end{array}$ \\
\hline Individually Purchased Supplemental Insurance & ------ & $\begin{array}{l}0.41^{* *} \\
(0.07) \\
{[0.14]}\end{array}$ \\
\hline Age & $\begin{array}{l}-0.018^{*} \\
(0.0074)\end{array}$ & $\begin{array}{l}-0.020 * * \\
(0.0074)\end{array}$ \\
\hline $\mathrm{Age}^{2}$ & $\begin{array}{l}0.00023^{* *} \\
(0.0001)\end{array}$ & $\begin{array}{l}0.00025^{* *} \\
(0.0001)\end{array}$ \\
\hline Male & $\begin{array}{l}-0.35^{* *} \\
(0.04)\end{array}$ & $\begin{array}{l}-0.34^{* *} \\
(0.04)\end{array}$ \\
\hline Married & $\begin{array}{c}0.02 \\
(0.04)\end{array}$ & $\begin{array}{c}0.01 \\
(0.04)\end{array}$ \\
\hline Secondary Education & $\begin{array}{l}0.06 \\
(0.05)\end{array}$ & $\begin{array}{c}0.08 \\
(0.05)\end{array}$ \\
\hline High School Education & $\begin{array}{c}0.09 \\
(0.06)\end{array}$ & $\begin{array}{c}0.10 \\
(0.06)\end{array}$ \\
\hline Higher Education & $\begin{array}{l}0.18^{* *} \\
(0.06)\end{array}$ & $\begin{array}{l}0.20^{* *} \\
(0.06)\end{array}$ \\
\hline Education Unknown & $\begin{array}{l}-0.11 \\
(0.10)\end{array}$ & $\begin{array}{l}-0.07 \\
(0.10)\end{array}$ \\
\hline Income: $€ 306$ to 457 & $\begin{array}{c}0.11 \\
(0.10)\end{array}$ & $\begin{array}{c}0.11 \\
(0.11)\end{array}$ \\
\hline Income: $€ 458$ to 610 & $\begin{array}{c}0.16 \\
(0.10)\end{array}$ & $\begin{array}{c}0.16 \\
(0.10)\end{array}$ \\
\hline Income: $€ 611$ to 762 & $\begin{array}{c}0.15 \\
(0.10)\end{array}$ & $\begin{array}{c}0.15 \\
(0.10)\end{array}$ \\
\hline Income: $€ 763$ to 915 & $\begin{array}{l}0.22 * \\
(0.10)\end{array}$ & $\begin{array}{l}0.20^{*} \\
(0.10)\end{array}$ \\
\hline Income: $€ 916$ to 1,220 & $\begin{array}{r}0.20^{*} \\
(0.10)\end{array}$ & $\begin{array}{c}0.20^{*} \\
(0.10)\end{array}$ \\
\hline Income: More than $€ 1,220$ & $\begin{array}{r}0.20^{*} \\
(0.10)\end{array}$ & $\begin{array}{c}0.18 \\
(0.10)\end{array}$ \\
\hline Income Unknown & $\begin{array}{l}-0.04 \\
(0.10)\end{array}$ & $\begin{array}{l}-0.05 \\
(0.10)\end{array}$ \\
\hline Self-Assessed Health = Fair/Poor & $\begin{array}{l}0.25^{* *} \\
(0.05)\end{array}$ & $\begin{array}{l}0.26^{* *} \\
(0.05)\end{array}$ \\
\hline Self-Assessed Health $=$ Excellent & $\begin{array}{l}-0.32 * * \\
(0.04)\end{array}$ & $\begin{array}{l}-0.31 * * \\
(0.04)\end{array}$ \\
\hline Self-Assessed Health $=$ Unknown & $\begin{array}{l}-0.16^{*} \\
(0.07)\end{array}$ & $\begin{array}{l}-0.18^{*} \\
(0.07)\end{array}$ \\
\hline Moderate to High Mortality Risk & $\begin{array}{l}0.27 * * \\
(0.04)\end{array}$ & $\begin{array}{l}0.27 * * \\
(0.04)\end{array}$ \\
\hline Disabled & $\begin{array}{l}0.25^{* *} \\
(0.05)\end{array}$ & $\begin{array}{l}0.25^{* *} \\
(0.05)\end{array}$ \\
\hline
\end{tabular}




\begin{tabular}{|c|c|c|}
\hline & $\begin{array}{c}\text { Indicator of } \\
\text { coverage }\end{array}$ & $\begin{array}{c}\text { Employment } \\
\text { based or } \\
\text { Individually } \\
\text { purchased }\end{array}$ \\
\hline Experiencing Frequent Pain & $\begin{array}{l}0.12^{* *} \\
(0.04)\end{array}$ & $\begin{array}{l}0.11^{*} \\
(0.04)\end{array}$ \\
\hline Pregnant Woman & $\begin{array}{l}1.25^{* *} \\
(0.15)\end{array}$ & $\begin{array}{l}1.25^{* *} \\
(0.15)\end{array}$ \\
\hline Former Smoker & $\begin{array}{l}0.14^{* *} \\
(0.04)\end{array}$ & $\begin{array}{l}0.14^{* *} \\
(0.04)\end{array}$ \\
\hline Light Smoker & $\begin{array}{l}-0.05 \\
(0.05)\end{array}$ & $\begin{array}{l}-0.05 \\
(0.05)\end{array}$ \\
\hline Heavy Smoker & $\begin{array}{l}-0.09 \\
(0.05)\end{array}$ & $\begin{array}{l}-0.09 \\
(0.05)\end{array}$ \\
\hline Inactive & $\begin{array}{l}-0.06 \\
(0.06)\end{array}$ & $\begin{array}{l}-0.05 \\
(0.06)\end{array}$ \\
\hline Unemployed & $\begin{array}{l}-0.03 \\
(0.07)\end{array}$ & $\begin{array}{l}-0.05 \\
(0.07)\end{array}$ \\
\hline Retired & $\begin{array}{c}0.10 \\
(0.06)\end{array}$ & $\begin{array}{c}0.08 \\
(0.06)\end{array}$ \\
\hline Students & $\begin{array}{l}-0.11 \\
(0.21)\end{array}$ & $\begin{array}{l}-0.06 \\
(0.21)\end{array}$ \\
\hline Farmers & $\begin{array}{l}-0.13 \\
(0.08)\end{array}$ & $\begin{array}{l}-0.14 \\
(0.08)\end{array}$ \\
\hline Artisans Retailers & $\begin{array}{l}-0.04 \\
(0.08)\end{array}$ & $\begin{array}{l}-0.03 \\
(0.08)\end{array}$ \\
\hline Executives and Intellectual Professions & $\begin{array}{c}0.09 \\
(0.06)\end{array}$ & $\begin{array}{c}0.08 \\
(0.06)\end{array}$ \\
\hline Technical Professions & $\begin{array}{c}0.00 \\
(0.05)\end{array}$ & $\begin{array}{c}0.00 \\
(0.05)\end{array}$ \\
\hline Skilled Workers & $\begin{array}{l}-0.01 \\
(0.05)\end{array}$ & $\begin{array}{l}-0.02 \\
(0.05)\end{array}$ \\
\hline Unskilled Workers & $\begin{array}{l}-0.02 \\
(0.06)\end{array}$ & $\begin{array}{l}-0.03 \\
(0.06)\end{array}$ \\
\hline Occupation Unknown & $\begin{array}{l}-0.09 \\
(0.11)\end{array}$ & $\begin{array}{l}-0.12 \\
(0.12)\end{array}$ \\
\hline Employed in the public sector & $\begin{array}{c}0.02 \\
(0.04)\end{array}$ & $\begin{array}{c}0.03 \\
(0.04)\end{array}$ \\
\hline High Density of Physicians & $\begin{array}{l}-0.05 \\
(0.04)\end{array}$ & $\begin{array}{l}-0.06 \\
(0.04)\end{array}$ \\
\hline Low Density of Physicians & $\begin{array}{l}-0.06 \\
(0.06)\end{array}$ & $\begin{array}{l}-0.06 \\
(0.06)\end{array}$ \\
\hline Constant & $\begin{array}{l}-0.87 * * \\
(0.21)\end{array}$ & $\begin{array}{l}-0.84^{* *} \\
(0.21)\end{array}$ \\
\hline $\begin{array}{l}\text { Number of Observations } \\
\text { Log-Likelihood }\end{array}$ & $\begin{array}{r}8,689 \\
-4,738\end{array}$ & $\begin{array}{r}8,689 \\
-4,592\end{array}$ \\
\hline
\end{tabular}

Notes: The dependent variable is equal to 1 for individuals who have any visits over a month and zero otherwise (probit regression). Standard errors in parentheses. Marginal effect on the probability of utilization in brackets (insurance coefficient only).

$* *$ : significant at the $1 \%$ level, $*: 5 \%$ level. 
Table 5. Partial Results for Alternative Probit Bivariate Models

\begin{tabular}{lccc}
\hline $\begin{array}{l}\text { Variables Excluded from } \\
\text { Utilization Equation }\end{array}$ & $\begin{array}{c}\text { Insurance } \\
\text { Coefficient } \\
\text { (std. error) }\end{array}$ & $\begin{array}{c}\rho \\
\text { (std. error) }\end{array}$ & $\begin{array}{c}\text { Likelihood } \\
\text { Ratio }\end{array}$ \\
\hline 1. None & 0.436 & ----- & ---- \\
2. Public employee & $(0.064)$ & & \\
& 0.544 & -0.056 & 0.094 \\
3. Public employee + Labor market & $(0.353)$ & $(0.184)$ & \\
$\quad$ status & $0.717^{* *}$ & -0.147 & 0.928 \\
4. Public employee + Professional & $(0.280)$ & $(0.154)$ & \\
occupation & $0.677^{*}$ & -0.127 & 0.556 \\
5. Public employee + Labor market & $(0.314)$ & $(0.170)$ & \\
$\quad$ status + Professional occupation & $0.859^{* *}$ & -0.227 & 2.578 \\
& $(0.242)$ & $(0.141)$ & \\
\hline \hline
\end{tabular}

Notes: The sample size for all models is 8,689.

The labor market status variables are indicators for the following categories: not in the labor force, unemployed, retired, student (the omitted category is actively employed). The professional occupation variables are indicators for the following categories: executive, technical professional, skilled worker, artisan retailer, farmer, unskilled worker, profession unknown (the omitted category is other employees). The model reported in row 1 includes all the potential instruments in the utilization equation. The likelihood ratios are calculated using restricted models that correspond to the bivariate models tested. The $\chi^{2}$ critical value for all models is 3.84 .

** : significant at the $1 \%$ level, * : $5 \%$ level. 
Table 6. Insurance Coverage and the Choice of Specialist Rather than a GP, Full Regression Results

\begin{tabular}{|c|c|c|}
\hline & All Visits & $\begin{array}{l}\text { Visits with } \\
\text { possible } \\
\text { substitution }\end{array}$ \\
\hline Covered by supplemental insurance & $\begin{array}{c}0.04 \\
(0.12)\end{array}$ & $\begin{array}{c}0.19 \\
(0.21)\end{array}$ \\
\hline Visit referred by a physician & $\begin{array}{l}1.22 * * \\
(0.06)\end{array}$ & $\begin{array}{l}1.18^{* *} \\
(0.10)\end{array}$ \\
\hline Age & $\begin{array}{l}0.028^{* *} \\
(0.011)\end{array}$ & $\begin{array}{c}0.01 \\
(0.018)\end{array}$ \\
\hline $\mathrm{Age}^{2}$ & $\begin{array}{l}-0.0004 \\
(0.0001)\end{array}$ & $\begin{array}{l}-0.0003 \\
(0.0002)\end{array}$ \\
\hline Male & $\begin{array}{l}-0.20 * * \\
(0.06)\end{array}$ & $\begin{array}{l}-0.30^{* *} \\
(0.10)\end{array}$ \\
\hline Married & $\begin{array}{l}-0.14^{*} \\
(0.06)\end{array}$ & $\begin{array}{l}-0.23^{*} \\
(0.10)\end{array}$ \\
\hline Secondary Education & $\begin{array}{l}-0.01 \\
(0.07)\end{array}$ & $\begin{array}{c}0.11 \\
(0.11)\end{array}$ \\
\hline High School Education & $\begin{array}{l}-0.00 \\
(0.09)\end{array}$ & $\begin{array}{c}0.18 \\
(0.14)\end{array}$ \\
\hline Higher Education & $\begin{array}{c}0.05 \\
(0.10)\end{array}$ & $\begin{array}{c}0.11 \\
(0.16)\end{array}$ \\
\hline Education Unknown & $\begin{array}{l}-0.05 \\
(0.16)\end{array}$ & $\begin{array}{l}-0.35 \\
(0.30)\end{array}$ \\
\hline Income: $€ 306$ to 457 & $\begin{array}{l}-0.11 \\
(0.17)\end{array}$ & $\begin{array}{l}-0.06 \\
(0.29)\end{array}$ \\
\hline Income: $€ 458$ to 610 & $\begin{array}{c}0.01 \\
(0.17)\end{array}$ & $\begin{array}{l}-0.10 \\
(0.28)\end{array}$ \\
\hline Income: $€ 611$ to 762 & $\begin{array}{c}0.12 \\
(0.16)\end{array}$ & $\begin{array}{l}-0.05 \\
(0.27)\end{array}$ \\
\hline Income: $€ 763$ to 915 & $\begin{array}{c}0.05 \\
(0.16)\end{array}$ & $\begin{array}{l}-0.12 \\
(0.27)\end{array}$ \\
\hline Income: $€ 916$ to 1,220 & $\begin{array}{c}0.20 \\
(0.16)\end{array}$ & $\begin{array}{l}-0.08 \\
(0.27)\end{array}$ \\
\hline Income: More than $€ 1,220$ & $\begin{array}{c}0.31 \\
(0.16)\end{array}$ & $\begin{array}{c}0.24 \\
(0.27)\end{array}$ \\
\hline Income Unknown & $\begin{array}{l}-0.04 \\
(0.17)\end{array}$ & $\begin{array}{r}-0.10 \\
0.27\end{array}$ \\
\hline Self-Assessed Health = Fair $/$ Poor & $\begin{array}{c}0.03 \\
(0.06)\end{array}$ & $\begin{array}{l}-0.08 \\
(0.10)\end{array}$ \\
\hline Self-Assessed Health $=$ Excellent & $\begin{array}{l}-0.01 \\
(0.07)\end{array}$ & $\begin{array}{l}-0.08 \\
(0.13)\end{array}$ \\
\hline Self-Assessed Health = Unknown & $\begin{array}{l}-0.03 \\
(0.11)\end{array}$ & $\begin{array}{c}0.13 \\
(0.19)\end{array}$ \\
\hline Moderate to High Mortality Risk & $\begin{array}{l}-0.12 \\
(0.06)\end{array}$ & $\begin{array}{l}-0.31 * * \\
(0.10)\end{array}$ \\
\hline Disabled & $\begin{array}{c}0.09 \\
(0.06)\end{array}$ & $\begin{array}{l}-0.10 \\
(0.11)\end{array}$ \\
\hline Experiencing Frequent Pain & $\begin{array}{c}0.02 \\
(0.06)\end{array}$ & $\begin{array}{c}0.11 \\
(0.10)\end{array}$ \\
\hline Pregnant Woman & $\begin{array}{l}0.77 * * \\
(0.14)\end{array}$ & $\begin{array}{c}0.09 \\
(0.58)\end{array}$ \\
\hline
\end{tabular}




\begin{tabular}{|c|c|c|}
\hline & All Visits & $\begin{array}{l}\text { Visits with } \\
\text { possible } \\
\text { substitution }\end{array}$ \\
\hline Former Smoker & $\begin{array}{l}0.13^{*} \\
(0.06)\end{array}$ & $\begin{array}{l}0.25^{*} \\
(0.10)\end{array}$ \\
\hline Light Smoker & $\begin{array}{c}0.08 \\
(0.08)\end{array}$ & $\begin{array}{l}-0.17 \\
(0.13)\end{array}$ \\
\hline Heavy Smoker & $\begin{array}{l}-0.08 \\
(0.08)\end{array}$ & $\begin{array}{l}-0.18 \\
(0.14)\end{array}$ \\
\hline Not in the Labor Force & $\begin{array}{c}0.03 \\
(0.09)\end{array}$ & $\begin{array}{l}0.06 \\
(0.14)\end{array}$ \\
\hline Unemployed & $\begin{array}{l}0.04 \\
(0.11)\end{array}$ & $\begin{array}{l}-0.14 \\
(0.18)\end{array}$ \\
\hline Retired & $\begin{array}{c}0.09 \\
(0.09)\end{array}$ & $\begin{array}{c}0.12 \\
(0.15)\end{array}$ \\
\hline Students & $\begin{array}{l}-0.47 \\
(0.32)\end{array}$ & $\begin{array}{l}-1.08 \\
(0.63)\end{array}$ \\
\hline Farmers & $\begin{array}{c}0.04 \\
(0.13)\end{array}$ & $\begin{array}{c}0.12 \\
(0.20)\end{array}$ \\
\hline Artisans Retailers & $\begin{array}{l}0.00 \\
(0.12)\end{array}$ & $\begin{array}{l}-0.14 \\
(0.21)\end{array}$ \\
\hline Executives and Intellectual Professions & $\begin{array}{c}0.11 \\
(0.09)\end{array}$ & $\begin{array}{c}0.04 \\
(0.16)\end{array}$ \\
\hline Technical Professions & $\begin{array}{c}0.05 \\
(0.07)\end{array}$ & $\begin{array}{l}-0.01 \\
(0.12)\end{array}$ \\
\hline Skilled Workers & $\begin{array}{l}-0.08 \\
(0.09)\end{array}$ & $\begin{array}{l}-0.04 \\
(0.15)\end{array}$ \\
\hline Unskilled Workers & $\begin{array}{l}-0.23 * \\
(0.10)\end{array}$ & $\begin{array}{l}-0.25 \\
(0.16)\end{array}$ \\
\hline Occupation Unknown & $\begin{array}{c}0.19 \\
(0.17)\end{array}$ & $\begin{array}{c}0.32 \\
(0.25)\end{array}$ \\
\hline High Density of Physicians & $\begin{array}{l}0.26 * * \\
(0.06)\end{array}$ & $\begin{array}{l}0.37 * * \\
(0.10)\end{array}$ \\
\hline Low Density of Physicians & $\begin{array}{l}-0.10 \\
(0.10)\end{array}$ & $\begin{array}{l}-0.09 \\
(0.16)\end{array}$ \\
\hline Constant & $\begin{array}{l}-0.97 * * \\
(0.33) \\
\end{array}$ & $\begin{array}{c}0.00 \\
(0.56) \\
\end{array}$ \\
\hline $\begin{array}{l}\text { Number of Observations } \\
\text { Log-Likelihood }\end{array}$ & $\begin{array}{c}3,591 \\
-2,042 \\
\end{array}$ & $\begin{array}{l}1,402 \\
-755 \\
\end{array}$ \\
\hline
\end{tabular}

Notes: The unit of observation is the visit. The dependent variable equals one if the visit is with a specialist and zero if it is with a general practitioner. Visits with possible substitution are defined as those prompted by conditions for which between $30 \%$ and $70 \%$ of patients visit a specialist (Source: ESPS 1992-1995).

** : significant at the $1 \%$ level, * : $5 \%$ level. 
Table 7. The Effect of Extending Supplemental Insurance Coverage on Income-Related Differences in the Utilization of Physician Services

\begin{tabular}{|c|c|c|c|c|}
\hline \multirow[b]{2}{*}{$\begin{array}{l}\text { Monthly income per } \\
\text { consumption unit }\end{array}$} & \multirow[b]{2}{*}{$\begin{array}{l}\text { \% of } \\
\text { Sample }\end{array}$} & \multicolumn{2}{|c|}{$\%$ with at least 1 visit } & \multirow[b]{2}{*}{$\begin{array}{l}\text { Change } \\
\text { (Predicted- } \\
\text { Actual) }\end{array}$} \\
\hline & & Actual & $\begin{array}{l}\text { Predicted if } \\
\text { Universal } \\
\text { Coverage }\end{array}$ & \\
\hline A. Less than $€ 458$ & $13.4 \%$ & $24.4 \%$ & $26.6 \%$ & $2.2 \%$ \\
\hline B. $€ 458$ to $€ 762$ & $27.1 \%$ & $27.7 \%$ & $28.6 \%$ & $0.9 \%$ \\
\hline C. $€ 763$ to $€ 1220$ & $33.2 \%$ & $30.7 \%$ & $31.3 \%$ & $0.6 \%$ \\
\hline D. More than $€ 1220$ & $26.4 \%$ & $32.5 \%$ & $33.1 \%$ & $0.6 \%$ \\
\hline All Adults & $100 \%$ & $28.7 \%$ & $29.6 \%$ & $0.9 \%$ \\
\hline \multicolumn{5}{|l|}{ Highest vs. lowest } \\
\hline Difference $(\mathrm{D}-\mathrm{A})$ & & $8.1 \%$ & $6.5 \%$ & \\
\hline Ratio (D/A) & & 1.332 & 1.241 & \\
\hline
\end{tabular}

Notes: Actual utilization represents the percent of individuals in each income category with at least one physician visit. Predicted utilization under universal coverage is calculated by estimating for each individual the probability of having at least one visit if covered by supplemental insurance and then calculating the mean of these fitted values for each category. Predictions are based on the regression model reported in Column 1 of Table 4. 